Quaternary Rodents and Lagomorphs of San Josecito Cave, Nuevo Leon, Mexico Author(s): J. E. Cushing, Jr.

Source: Journal of Mammalogy, Vol. 26, No. 2 (May, 1945), pp. 182-185

Published by: American Society of Mammalogists

Stable URL: https://www.jstor.org/stable/1375094

Accessed: 02-09-2021 20:22 UTC

\title{
REFERENCES
}

Linked references are available on JSTOR for this article:

https://www.jstor.org/stable/1375094?seq=1\&cid=pdf-reference\#references_tab_contents You may need to log in to JSTOR to access the linked references.

JSTOR is a not-for-profit service that helps scholars, researchers, and students discover, use, and build upon a wide range of content in a trusted digital archive. We use information technology and tools to increase productivity and facilitate new forms of scholarship. For more information about JSTOR, please contact support@jstor.org.

Your use of the JSTOR archive indicates your acceptance of the Terms \& Conditions of Use, available at https://about.jstor.org/terms

American Society of Mammalogists is collaborating with JSTOR to digitize, preserve and extend access to Journal of Mammalogy 
1903. Putorius streatori leptus Merriam, Proc. Biol. Soc. Washington, vol. 16, p. 76. May 29, 1903. Type from Silverton, San Juan County, Colorado.

Type Locality.-Echo, $7500 \mathrm{ft}$., El Dorado County, California.

Range.-Principally boreal life-zones from central and southwestern Montana, southern Idaho, and Blue Mountains of southeastern Washington southward east of the Cascade Divide through the Salmon River Mountains and Sierra Nevada at least into Fresno County of California, in the Great Basin to central Nevada, and in the Rocky Mountains into northern New Mexico.

University of Kansas, Lawrence, Kansas.

\section{QUATERNARY RODENTS AND LAGOMORPHS OF SAN JOSECITO CAVE, NUEVO LEON, MEXICO}

\section{By J. E. Cushing, Jr.}

This paper is a report on the rodents and lagomorphs found in the deposits of San Josecito Cave, near the town of Aramberri, southern Nuevo Leon, Mexico. The cave is approximately 7,400 feet above sea-level in mountainous country that, in this vicinity, supports a forest cover of pine and oak. The inhabitants of the region long believed that the cave contained buried treasure and in searching for this disturbed the floor to a depth of several feet. Subsequent operations by workers from the California Institute of Technology extended the diggings some sixty or seventy feet, which evidentally is near the bottom of the fossiliferous deposit. The cave accumulation includes a wealth of ossiferous material, the remains of thousands of individuals that either fell or were carried into the cave in late Pleistocene time. The fauna includes antelope (Stockoceros conklingi), deer, large ovibovid (Preptoceras), horse (Equus), ground sloth (Nothrotherium), sabre tooth cat (Smilodon), dire wolf (Aenocyon) and a vampire bat. Some of these forms are well represented. There is likewise a large variety of smaller mammals and birds (Miller, 1943).

\section{REVIEW OF THE RODENTS AND LAGOMORPHS}

Following is a list of the rodents and lagomorphs occurring in the Quaternary deposits of San Josecito Cave:

\author{
Marmota (marmot) \\ Citellus (ground squirrel) \\ Sciurus (tree squirrel) \\ Thomomys (pocket gopher) \\ 2 unidentified geomyids \\ Liomys (pocket mouse) \\ Reithrodontomys (harvest mouse)
}

\author{
Peromyscus (white-footed mouse) \\ Sigmodon (cotton rat) \\ Neotoma (wood rat) \\ Synaptomys cooperi (lemming mouse) \\ Microtus (meadow mouse) \\ Sylvilagus leonensis, n. sp. (dwarf rabbit) \\ Sylvilagus sp.? (cottontail rabbit)
}

The remains of some individual kinds of rodents in the cave are present in large numbers. This abundance seems to have resulted mostly from the work of raptorial birds that inhabited the area. Because only a few specimens of small Recent mammals for comparative use in identifying species are available from 
the San Josecito area, no attempt is now made to determine more than the generic identity of most of the species.

Rabbits are well represented, the bones of several hundred individuals having been collected. These belong to two species of Sylvilagus. One, by far the most abundant, is referable to the cottontail group. The other is a pigmy form with size comparable to that of the living pigmy rabbit (Sylvilagus idahoensis). Nevertheless, the Mexican leporid from San Josecito Cave is not as closely related to $S$. idahoensis or the rarer Romerolagus diazi of Mexico (both apparently relics with restricted ranges that do not include the cave area) as to the cottontails. However, it is much smaller than any known cottontail or brush rabbit and apparently represents a new species.

TABLE 1.-Comparative measurements (in millimeters)

\begin{tabular}{|c|c|c|c|c|}
\hline & $\begin{array}{c}\text { WIDTH } \\
\text { ACROSS } \\
\text { INCISIVE } \\
\text { FORAMINA }\end{array}$ & $\begin{array}{c}\text { LENGTH OF } \\
\text { LEFT UPPER } \\
\text { CHEER-TOOTH } \\
\text { SERIES }\end{array}$ & $\begin{array}{l}\text { WIDTH OF } \\
\text { PALATE }\end{array}$ & $\begin{array}{l}\text { WIDTH OF } \\
\text { CHOANAEE }\end{array}$ \\
\hline $\begin{array}{r}\text { Sylvilagus leonensis C.I.T. Vert. Paleo. No. } \\
3212 \ldots \ldots \ldots \ldots \ldots \ldots \ldots \ldots \ldots \ldots \ldots \ldots \ldots \ldots\end{array}$ & 4.7 & 10.1 & 6.2 & 3.4 \\
\hline C.I.T. Vert. Paleo. No. $3211 \ldots \ldots \ldots \ldots \ldots$ & 4.5 & 10.1 & 5.5 & 3.6 \\
\hline C.I.T. Vert. Paleo. No. $3209 \ldots \ldots \ldots \ldots \ldots$. & 4.9 & 9.6 & 5.2 & 3.5 \\
\hline C.I.T. Vert. Paleo. No. $3210 \ldots \ldots \ldots \ldots$ & 4.4 & 9.2 & 4.7 & 3.9 \\
\hline C.I.T. Vert. Paleo. No. $3213 \ldots \ldots \ldots \ldots \ldots$ & 5.5 & 10.1 & 5.4 & - \\
\hline $\begin{array}{l}\text { Sylvilagus idahoensis Dickey collection. No. } \\
\quad 17274,+\ldots \ldots \ldots \ldots \ldots \ldots \ldots \ldots \ldots \ldots \ldots \ldots \ldots \ldots \ldots\end{array}$ & 6.4 & 9.1 & 3.8 & 4.6 \\
\hline Dickey collection No. $\frac{9061}{2910}, \sigma^{7} \ldots \ldots \ldots \ldots$ & 6.5 & 8.8 & 3.4 & 4.7 \\
\hline $\begin{array}{l}\text { M.V.Z. No. } 36361, \text { }, \ldots \ldots \ldots \ldots \ldots \ldots \ldots \ldots \\
\text { M.V.Z. No. } 36362, \sigma^{2} \ldots \ldots \ldots \ldots \ldots \ldots \ldots\end{array}$ & $\begin{array}{l}5.8 \\
6.4\end{array}$ & $\begin{array}{l}9.0 \\
9.0\end{array}$ & $\begin{array}{l}3.9 \\
3.7\end{array}$ & $\begin{array}{l}4.0 \\
4.1\end{array}$ \\
\hline
\end{tabular}

Sylvilagus leonensis, $n$. sp.

Type specimen.-Complete left ramus, no. 3208, California Institute of Technology, Vert. Paleo. Coll.

Co-type.-Palatal portion of skull, no. 3209, C.I.T. Vert. Paleo. Coll., lacking $\mathrm{M}^{1}$ and $\mathrm{M}^{3}$ of the left side, and $\mathrm{P}^{2}$ and $\mathrm{M}^{3}$ of the right.

Additional Material.-25 right rami and 33 left rami, 5 entire palates and portions of 13 others; 5 adult humeri, 2 femora, 3 ulnae, and one radius.

Locality.-Calif. Inst. Tech. Vert. Paleo. Loc. 192, San Josecito Cave Pleistocene, southern Nuevo Leon, Mexico.

Diagnosis.-Referable to subfamily Leporinae (Dice, 1929) on basis of enamel folding of $\mathrm{PM}_{3}$; and to the genus Sylvilagus on basis of enamel pattern of molariform teeth, small size, and the relatively long palate as compared to the width of choanae and incisive foramina (Lyon, 1903). The cave rabbit can be readily distinguished from all known species of Sylvilagus except idahoensis by its smaller size, and from the latter species by the following characters: (1) much wider palate, which exceeds width of choanae (see Table 1 for comparative measurements); (2) external re-entrant angle of upper molariform teeth crenulate, par- 
ticularly on anterior edge; (3) $\mathrm{PM}_{3}$ with broad shallow re-entrant angle (none in idahoensis); (4) posterior portion of lower molariform teeth, except $\mathrm{M}_{3}$, relatively wider in relation to anterior portion than in idahoensis.

Discussion of characters.-Comparison of the material listed shows that the diagnostic characters given above are constant insofar as these can be determined, with one partial exception. The anterior re-entrant angle in $\mathrm{PM}_{3}$, although always present, is variable in degree of expression and is crenulate in one of the eighteen teeth examined. This specimen is exceptional, but its peculiarity may be due to extreme wear.

The large number of rabbits occurring in the deposits gives added significance to the fact that no bones referable to the hares (genus Lepus) have been found. If a moderate or large population of hares existed near the cave during the time of accumulation of the deposits, the population probably would have been sampled by the larger birds of prey that were then prevalent. Hares occur, at least in the general region, about the cave at present (Nelson, 1909).

\section{RODENT ASSEMBLAGE}

Another animal whose range definitely has changed is the marmot (Marmota sp.), represented, however, by the rami of only two left lower jaws. Unfortunately these do not suffice to tell which of the three modern species was present, a fact that would be of interest, for these species occupy different habitats today. However, no living marmots of any kind now range into Mexico. The closest approach is made by colonies of the yellow-bellied marmot (Marmota flaviventer obscura) that inhabit the mountains of northern New Mexico (Howell, 1915). Further evidence that the range of the genus has changed within Recent times is found in the presence of skeletal remains of the species flaviventer in the New Mexican mountains somewhat to the south of the present colonies (Howell, op. cit., p. 55), yet still north of the Mexican boundary.

One other species that has changed its range since entombment in the cave deposits is the lemming mouse (Synaptomys cooperi subsp. ?), of which several mandibles were taken from the surface layers of the cave. This is the only instance where a form obtained in the disturbed surface layers of the cave has not been found subsequently at greater depths. According to Howell (1937) lemming mice live as far south as Arkansas in the Upper Austral Life-zone along the eastern border of the Great Plains. On the Atlantic slope they range southward into North Carolina. Howell reports that at these extreme southerly localities Synaptomys cooperi lives mostly in cold sphagnum bogs, although it has been trapped in moist and dry grass lands. In the state of New York these mice have been found to live in heavily forested areas and appear to be colonial in habit (Hamilton, 1941, p. 195). Apparently cooperi does not require a particularly cold climate. Such a view is in agreement with the conditions suggested by the remainder of the Pleistocene fauna recorded from San Josecito Cave. The one additional microtine rodent in the collection belongs to the genus Microtus; the remains of this meadow mouse far outnumber those of the lemming mouse. 
At least three kinds of gophers are found in the cave deposits. The most abundant form is Thomomys. A few cranial and limb bones indicate the presence of two larger forms. Unfortunately material of the latter is too fragmentary to permit generic identification.

Sciurus and Citellus have been identified on the basis of a skull and three mandibles. The ground squirrel is represented by rami of lower jaws comparable in size to that of Ammospermophilus.

Aside from a single mandible of an immature porcupine (Erethizon ?) and skulls of many spiny pocket mice (Liomys), the remainder of the rodent remains consists of jaws and skeletal parts of several hundred cotton rats (Sigmodon), wood rats (Neotoma), harvest mice (Reithrodontomys) and white-footed mice (Peromyscus), all cricetine rodents.

Unfortunately, the San Josecito rodent fauna is not particularly indicative of the past climate of the region, although it suggests that the conditions in which it lived were similar to those encountered in the area today. Irrespective of the extent to which the climate of the country may have changed, the excavations already show a considerable faunistic difference between the time of the Pleistocene animals and that of the present.

The deposit was called to the attention of the California Institute of Technology by J. W. Patterson and has been extensively excavated under the direction of Dr. Chester Stock. It was at the suggestion of Dr. Stock and under his guidance that the present study was carried out. I should like to thank persons in charge of the Donald R. Dickey Collection, the U. S. National Museum, the California Academy of Sciences, and the Museum of Vertebrate Zoology, University of California, for advice and for the loan of several specimens.

Balch Graduate School of the Geological Sciences, California Institute of Technology, Pasadena, California, Contribution No. 341.

\section{LITERATURE CITED}

Dice. L. R. 1929. The phylogeny of the Leporidae, with description of a new genus. Jour. Mamm., vol. 10, pp. 340-344, 1 fig.

Furlong, E. L. 1943. The Pleistocene antelope, Stockoceros conklingi, from San Josecito Cave, Mexico. Carnegie Inst. Washington, publ. 551, pp. 1-8.

Hamilton, W. J. JR. 1941. On the occurrence of Synaptomys cooperi in forested regions. Jour. Mamm., vol. 22, p. 195.

Howell, A. H. 1915. Revision of the American marmots. U. S. Dept. Agric., Bur. Biol. Surv., N. A. Fauna, 37, pp. 1-80, 15 pls., 3 figs.

Howell, A. B. 1927. Revision of the American lemming mice (Genus Synaptomys). U. S. Dept. Agric., Bur. Biol. Surv., N. A. Fauna, 50, pp. 1-38, 2 pls., 11 figs.

Lyon, M. W. JR. 1903. Classification of the hares and their allies. Smithson. Misc. Coll., vol. 45 (no. 1456), pp. 321-447, 27 pls., 2 figs.

Miller, G. S. 1924. List of North American Recent mammals, 1923. U. S. Nat. Mus. Bull., 128, pp. xvi +673 .

Miller, Loye. 1943. The Pleistocene birds of San Josecito Cavern, Mexico. Univ. California Publ. Zool., vol. 47, pp. 143-168.

Nelson, E. W. 1909. The rabbits of North America. U. S. Dept. Agric., Bur. Biol. Surv., N. A. Fauna, 29, pp. 1-314, 13 pls., 18 figs.

California Institute of Technology, Pasadena, California. 